\title{
Flavobacterium amnigenum sp. nov. Isolated from a River ${ }^{\mathrm{S}}$
}

\author{
Kishor Sureshbhai Patil ${ }^{1}$, Shalem Raj Padakandla ${ }^{1,2}$, and Jong-Chan Chae ${ }^{1 *}$ \\ ${ }^{1}$ Division of Biotechnology, Chonbuk National University, Iksan 54596, Republic of Korea \\ ${ }^{2}$ Jhaveri Microbiology Centre, Brien Holden Eye Research Centre, L. V. Prasad Eye Institute, Kallam Anji Reddy campus, Hyderabad, India
}

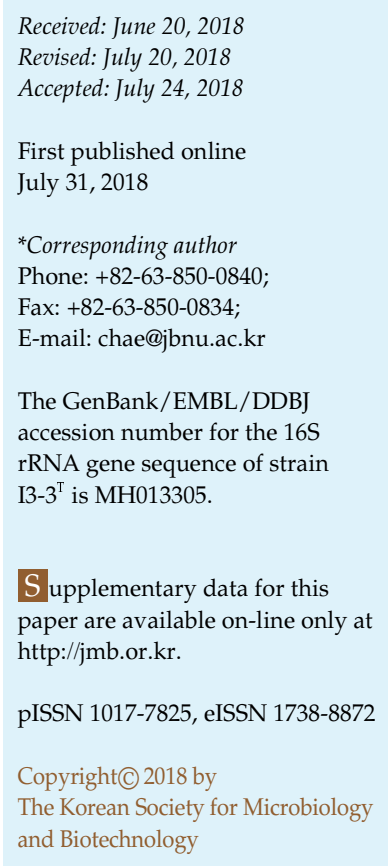

A yellowish, flexirubin-pigment-producing strain $\mathrm{I} 3-3^{\mathrm{T}}$ was isolated from river water in Iksan, the Republic of Korea. The strain was gram-negative, aerobic, non-motile, showed catalase and oxidase activities, and could grow at a temperature range of $10-35^{\circ} \mathrm{C}, \mathrm{pH} 5.0-10$ and $0-$ $2.0 \%(\mathrm{w} / \mathrm{v})$ of $\mathrm{NaCl}$. The major fatty acids were iso- $\mathrm{C}_{15: 0}$, iso- $\mathrm{C}_{17: 0} 3-\mathrm{OH}$ and summed feature 3 (comprising $\mathrm{C}_{16: 1} \omega 7 \mathrm{c}$ and/or $\mathrm{C}_{16: 1} \omega 6 \mathrm{c}$ ). The isolate contained phosphatidylethanolamine, one aminolipid, and two unidentified lipids as the major polar lipids. Menaquinone-6 (MK6) was the major respiratory quinone. The $\mathrm{G}+\mathrm{C}$ content of the genomic DNA of strain $\mathrm{I} 3-3^{\mathrm{T}}$ was $35.6 \%$. Comparison of the 16S rRNA gene sequence with the sequences of the closely related type strains showed highest sequence similarity of $96.95 \%$ and $96.93 \%$ to Flavobacterium nitrogenifigens NXU-44 $4^{\mathrm{T}}$ and Flavobacterium compostarboris $15 \mathrm{C} 3^{\mathrm{T}}$, respectively. Based on phenotypic and phylogenetic distinctiveness, strain $\mathrm{I} 3-3^{\mathrm{T}}$ is considered as a member of novel species within the genus Flavobacterium, for which Flavobacterium amnigenum sp. nov. is proposed. The type strain is $\mathrm{I} 3-3^{\mathrm{T}}\left(=\mathrm{KCTC} 52884^{\mathrm{T}}=\mathrm{NBRC} 112871^{\mathrm{T}}\right)$.

Keywords: Flavobacterium amnigenum, freshwater, polyphasic characterization

\section{Introduction}

The genus Flavobacterium belonging to the family Flavobacteriaceae was proposed to accommodate gramnegative, rod-shaped, aerobic, yellow-pigment-producing, non-spore-forming, motile by gliding, and chemoorganotrophic bacteria [1]. They have menaquinone-6 (MK6) as the major respiratory quinone. DNA G+C content of the genus is in the range of 30-52 mol\% [2]. Production of yellow pigments, catalase activity, having no requirement for sodium ions or seawater, inability to produce indole and growth under anaerobic conditions or at above $37^{\circ} \mathrm{C}$ are the key features of the genus [3]. Currently, the genus Flavobacterium contains around 203 species with validly published names (http://www.bacterio.net/flavobacterium. html) and have been isolated from various habitats including fresh and marine water, soil, diseased fish, and microbial mats [4, 5]. During an attempt to study the distribution and diversity of antibiotic resistant bacteria in water bodies, strain $\mathrm{I} 3-3^{\mathrm{T}}$ was obtained from a river sample. Present work used a polyphasic approach to indicate the taxonomic position of strain $13-3^{\mathrm{T}}$ and to propose it as a novel species within the genus Flavobacterium.

\section{Materials and Methods}

\section{Strain Isolation and Culture Condition}

A water sample from a river in Iksan, the Republic of Korea, was serially diluted 10 fold in saline $(\mathrm{NaCl}, 0.85 \%(\mathrm{w} / \mathrm{v}))$ and $100 \mu \mathrm{l}$ of each dilution was spread on to Mueller Hinton (MH) agar plates containing gentamycin $(8 \mu \mathrm{g} / \mathrm{ml})$. After incubation at $30^{\circ} \mathrm{C}$ for $48 \mathrm{~h}$, a yellow-pigmented colony was selected and designated as strain $13-3^{\mathrm{T}}$. The isolate was purified by repeated streaking on $\mathrm{MH}$ agar plates, maintained under refrigeration at $4^{\circ} \mathrm{C}$, and preserved as glycerol $(20 \%, v / v)$ stock at $-80^{\circ} \mathrm{C}$. For comparative taxonomic studies, the type strains of Flavobacterium nitrogenifigens NXU-44 ${ }^{\mathrm{T}}$ (=KACC $\left.14224^{\mathrm{T}}\right)$ and Flavobacterium compostarboris $15 \mathrm{C}^{\mathrm{T}}$ (=BCCM/LMG $28694^{\mathrm{T}}$ ) were purchased from Belgian Co-ordinated Collections of Microorganisms (BCCM/ 
LMG) and Korean Agricultural Culture Collection (KACC), respectively.

\section{S rRNA Gene Sequencing and Phylogenetic Analysis}

For $16 \mathrm{~S}$ rRNA gene sequencing, total genomic DNA was isolated with a bacterial genomic DNA isolation kit (Exgene Cell SV mini, GeneAll). PCR amplification and sequencing of the $16 \mathrm{~S}$ rRNA gene were performed using universal primers 27F (5'AGAGTTTGATCMTGGCTCAG-3') and 1492R (5'-TACGGYTAC CTTGTTACGACTT-3') as described previously by Padakandla et al. [6]. The determined 16S rRNA gene sequences were assembled using SeqMan software (Lasergene, DNASTAR) and the contig sequence $(1,482 \mathrm{bp})$ of strain $\mathrm{I} 3-3^{\mathrm{T}}$ was compared with available 16S rRNA gene sequences of culturable species in the EzBioCloud database (http://www.ezbiocloud.net/) [7]. Phylogenetic analysis with 16S rRNA gene sequences of strain I3- $3^{\mathrm{T}}$ and the most closely related type strains belonging to the family Flavobacteriaceae was performed using maximum likelihood (ML), neighbour-joining (NJ) and minimum evolution (ME) methods in MEGA6 software [8]. Evolutionary distances were calculated using Kimura's 2parameter correction in a complete deletion procedure for ML tree and pairwise deletion procedure for $\mathrm{NJ}$ and ME trees [9]. Percentage support values were obtained using a bootstrap procedure with 1,000 replications [10]. The obtained 16S rRNA gene sequence of strain I3-3 ${ }^{\mathrm{T}}$ was deposited under the GenBank/ EMBL/DDBJ accession number MH013305.

\section{Morphological, Physiological, and Biochemical Characterization}

Growth of isolate $\mathrm{I} 3-3^{\mathrm{T}}$ and two reference strains, NXU-44 $4^{\mathrm{T}}$ and $15 \mathrm{C}^{\mathrm{T}}$, at $30^{\circ} \mathrm{C}$ for $48 \mathrm{~h}$ were tested on the following bacteriological media such as nutrient agar (NA), brain heart infusion agar, R2A agar, tryptic soy agar (TSA), Luria-Bertani agar (LB) and MacConkey agar. Since all three strains showed optimum growth on TSA, further cultural and morphological comparative characterization was conducted on TSA/tryptone soy broth (TSB) following the recommended standards proposed by Bernardet et al. [11] and Tindall et al. [12]. Gram reaction was performed using Gram stain kit (Difco) according to the manufacturer's instructions and also by non-staining $\mathrm{KOH}$ method [13]. Following the protocol mentioned earlier by Sirra et al. [14], cell shape and size was assessed using a Supra 40VP field emission scanning electron microscope (Zeiss). Motility was observed with 1,000 $\times$ magnification using a phase-contrast light microscope (Primo Star; Zeiss). Spore formation was investigated by staining the cells of $72 \mathrm{~h}$ old cultures with malachite green according to Schaeffer and Fulton [15]. Oxidase activity was determined by $1 \%$ aqueous solution of $N, N, N, N$-tetramethyl-p-phenylenediamine dihydrochloride and catalase activity was examined using $3 \%(\mathrm{v} / \mathrm{v}) \mathrm{H}_{2} \mathrm{O}_{2}$ solution [16]. According to Bernardet et al. [11], the presence of flexirubin-type pigments was tested using $20 \%(\mathrm{w} / \mathrm{v}) \mathrm{KOH}$ solution and the presence of extracellular galactosamine glycan was investigated by Congo red absorption method in which colonies on agar plates were directly flooded with $0.01 \%$ aqueous Congo red solution.
Capnophilic growth was observed on TSA incubating in a $\mathrm{CO}_{2}$ incubator $\left(5 \% \mathrm{CO}_{2}\right)$ for $72 \mathrm{~h}$. The temperature range for growth was examined at $5-50^{\circ} \mathrm{C}$ with an interval of $5^{\circ} \mathrm{C}$ on TSB. Tolerance to $\mathrm{NaCl}$ was investigated in TSB supplemented with $0.5-8.0 \%(\mathrm{w} / \mathrm{v}) \mathrm{NaCl}(0.5 \%$ interval) and $\mathrm{pH}$ tolerance was tested on the same medium by adjusting $\mathrm{pH}$ to $4-12$ (in increments of $1.0 \mathrm{pH}$ unit) using phosphate-citrate (4.0-6.5), Tris- $\mathrm{HCl}$ (7.0-9.0), $\mathrm{NaHCO}_{3}-\mathrm{NaOH}(9.5-11.0)$, and $\mathrm{Na}_{2} \mathrm{HPO}_{4}-\mathrm{NaOH}(11.5-12.0)$ buffer systems.

Hydrolysis of skim milk (1\%, w/v), carboxymethyl-cellulose (CMC) $(0.5 \%, \mathrm{w} / \mathrm{v})$, casein $(1 \%, \mathrm{w} / \mathrm{v})$, starch $(1 \%, \mathrm{w} / \mathrm{v})$, tween-20 $(1 \%, \mathrm{v} / \mathrm{v})$, and tween-80 $(1 \%, \mathrm{v} / \mathrm{v})$ was observed on $1.5 \%$ agar and clear zone formation around colonies was recorded after $48 \mathrm{~h}$ incubation [17]. Susceptibility of strain I3- $3^{\mathrm{T}}$ and the two reference strains against various antibiotics was conducted by the KirbyBauer disc diffusion method [18] after spreading cell suspensions on $\mathrm{MH}$ agar plates. The discs contained the following antibiotics $(\mu \mathrm{g} /$ disc): gentamicin (120), amoxicillin (30), cephalexin (30), tetracycline (30), erythromycin (15), tylosin (30), kanamycin (30), ciprofloxacin (5), clindamycin (2), vancomycin (30), sulfamethoxazole (50), trimethoprim (5), ofloxacin (5), lincomycin (15), norfloxacin (10), tobramycin (30), imipenem (10), penicillin (10), oxytetracycline (30), ampicillin (10), and amikacin (30). The antibiotic susceptibility to the cell growth was determined after $24 \mathrm{~h}$ incubation. Following the manufacturer's instructions, acid production from carbohydrates, enzyme activities, and other biochemical tests were performed using API 50CH, API 20E, API 20NE, and API ZYM kits (bioMerieux).

\section{Chemotaxonomic Characterization}

Polar lipids were extracted from $150 \mathrm{mg}$ freeze-dried cells following the integrated protocol described by Minnikin et al. [19] and separated by two dimensional chromatography on silica gel TLC plates (Kieselgel 60 F254, Merck). Separation was performed using chloroform/methanol/water (65:25:4, v/v/v) and chloroform/ methanol/acetic acid/water (80:12:15:4, v/v/v/v) as mobile phases in the first and second dimensions, respectively [20]. Plates were sprayed with $5 \%$ ethanolic molybdophosphoric acid to detect the total polar lipids, and the reagents ninhydrin, molybdenum blue or $\alpha$-naphthol to detect amino or phosphate groups, respectively [21,22]. For comparison of cellular fatty acid composition, strains $\mathrm{I} 3-3^{\mathrm{T}}, \mathrm{NXU}-44^{\mathrm{T}}$, and $15 \mathrm{C}^{\mathrm{T}}$ were grown on TSA for $48 \mathrm{~h}$. According to the instructions for the Microbial Identification System (Microbial ID; MIDI, version 6.0), fatty acid methyl esters were prepared, separated, and identified [23]. As described by Tamaoka et al. [24], quinones were extracted from wet culture pellets by shaking with chloroform/methanol (2:1, v/v) for 3-4 h. After the suspension was filtered with Whatman No.2 filter paper, the filtrate was concentrated and suspended in $100 \mu \mathrm{l}$ chloroform/methanol $(8.5: 1.5, \mathrm{v} / \mathrm{v})$. It was centrifuged with $12,000 \times g$ for $5 \mathrm{~min}$ and the supernatant was analyzed by HPLC (YOUNG LIN YL9100 (YL9111 Binary pump); solvent system, methanol/isopropyl ether $(4: 1, \mathrm{v} / \mathrm{v})$; flow rate $1.0 \mathrm{ml} \mathrm{min}^{-1}$; 
Spherisorb $5 \mu \mathrm{m}$ ODS2 column $(4.6 \times 150 \mathrm{~mm}$, Waters); YOUNG LIN YL9120 UV/Vis detector; detection wavelength $254 \mathrm{~nm}$ ). Data analysis was carried out using YOUNG LIN Autochro-3000 software. Extraction and purification of genomic DNA was carried out following the protocol mentioned by Marmur et al. [25] and the $\mathrm{mol} \% \mathrm{G}+\mathrm{C}$ of the DNA was determined by HPLC method [26].

\section{Results and Discussion}

Cells of strain $13-3^{\mathrm{T}}$ grown on TSA were rod shaped, gram-negative and formed visible dark yellowish colonies (diameter about $2 \mathrm{~mm}$ ) within $48 \mathrm{~h}$ at $30^{\circ} \mathrm{C}$. The colonies were convex shaped, translucent, glistening with entire edges, and produced flexirubin type of pigment which was indicated by an immediate color shift from yellow to orange red after addition of $20 \%(\mathrm{w} / \mathrm{v}) \mathrm{KOH}$ solution. Strain $13-3^{\mathrm{T}}$ was positive for oxidase and catalase activities, but negative for Congo red absorption. Under microscopic examination, the strain was non-motile and non-sporeforming rods with $1.0-4.0 \mu \mathrm{m}$ in length and $0.3-0.4 \mu \mathrm{m}$ in width (Figs. S1 and S2). Optimal growth was observed on TSA and the strains could also grow on used other culture media except for MacConkey agar. Strain $\mathrm{I} 3-3^{\mathrm{T}}$ grew over a temperature range of $15-30^{\circ} \mathrm{C}$ with an optimum at $30^{\circ} \mathrm{C}$ but showed significant weak growth at temperatures $10^{\circ} \mathrm{C}$ and $35^{\circ} \mathrm{C}$. The strain showed optimum growth at $0.5 \%(\mathrm{w} / \mathrm{v})$ of $\mathrm{NaCl}$. Although additional salt was not required for the growth of strain $\mathrm{I} 3-3^{\mathrm{T}}$, it could tolerate up to $2 \% \mathrm{NaCl}(\mathrm{w} / \mathrm{v})$. Growth occurred over $\mathrm{pH}$ range of 5.0-10 with optimum $\mathrm{pH}$ of 7.0. No growth was observed in the presence of $5 \%$ $\mathrm{CO}_{2}$. It was also observed that strain $\mathrm{I} 3-3^{\mathrm{T}}$ exhibited resistance to gentamicin, amoxicillin, erythromycin, kanamycin, vancomycin, trimethoprim, tobramycin, imipenem, amikacin, ampicillin, and penicillin. However, it was sensitive to cephalexin, tetracycline, tylosin, ciprofloxacin, clindamycin, sulfamethoxazole, ofloxacin, lincomycin, norfloxacin, and oxytetracycline. Comparison of the physiological and biochemical characteristics of strain $\mathrm{I} 3-3^{\mathrm{T}}$ with those of the closely related species was shown in Table 1.

Phylogenetic analysis revealed that the closest phylogenetic neighbors of strain $\mathrm{I} 3-3^{\mathrm{T}}$ were Flavobacterium nitrogenifigens NXU- $44^{\mathrm{T}}$ and Flavobacterium compostarboris $15 \mathrm{C}^{\mathrm{T}}$ with sequence similarities of $96.95 \%$ and $96.93 \%$. Strain $\mathrm{I} 3-3^{\mathrm{T}}$ closely clustered with the members of genus Flavobacterium and formed a separate clade along with Flavobacterium compostarboris $15 \mathrm{C}^{\mathrm{T}}$ in the phylogenetic tree (Fig. 1). DNA $\mathrm{G}+\mathrm{C}$ content of strain $\mathrm{I} 3-3^{\mathrm{T}}$ was $35.6 \mathrm{~mol} \%$.

The polar lipids of strain $13-3^{\mathrm{T}}$ were identified as
Table 1. Comparison of the physiological characteristics of strain $\mathrm{I} 3-3^{\mathrm{T}}$ with those of closely related species of the genus Flavobacterium.

\begin{tabular}{|c|c|c|c|}
\hline Characteristic & 1 & 2 & 3 \\
\hline Cell shape and size & Rods & Rods & Rods \\
\hline (length $\times$ diameter) & $1.0-4.0$ & $1.0 \times 2.0$ & $1.1-7.2$ \\
\hline$(\mu \mathrm{m})$ & $\times 0.3-0.4$ & & $\times 0.3-0.7$ \\
\hline Colony color & Yellow & Yellow & Orange yellow \\
\hline $\begin{array}{l}\text { Growth temperature } \\
\text { range and optimum }\left({ }^{\circ} \mathrm{C}\right)\end{array}$ & $10-35(30)$ & $15-30(25)$ & $10-30(25)$ \\
\hline pH range (optimum) & $5.0-10(7.0)$ & $5.0-10(7.0)$ & $6.0-8.0(6.0)$ \\
\hline $\mathrm{NaCl}$ tolerance $\%(\mathrm{w} / \mathrm{v})$ & $0.0-2.0 \%$ & $0.0-1.0 \%$ & $0.0-2.0 \%$ \\
\hline Oxidase & + & + & - \\
\hline \multicolumn{4}{|l|}{ Hydrolysis of } \\
\hline Tween-20 & - & + & + \\
\hline $\begin{array}{l}\text { Carboxymethyl- } \\
\text { cellulose (CMC) }\end{array}$ & - & - & + \\
\hline \multicolumn{4}{|l|}{ Assimilation of: } \\
\hline D-Xylose & - & $\mathrm{w}$ & $\mathrm{w}$ \\
\hline D-Fructose & + & - & - \\
\hline Salicin & - & $\mathrm{w}$ & $\mathrm{w}$ \\
\hline D-Lactose & - & - & + \\
\hline D-Saccharose & + & - & - \\
\hline D-Trehalose & - & $\mathrm{w}$ & $\mathrm{w}$ \\
\hline Glycogen & $\mathrm{w}$ & $\mathrm{w}$ & - \\
\hline \multicolumn{4}{|l|}{ Biochemical characters } \\
\hline ONPG & - & + & + \\
\hline Urease & - & + & - \\
\hline Voges Proskauer test & - & + & - \\
\hline Nitrate reduction & + & - & - \\
\hline$\beta$-glucosidase & - & - & + \\
\hline DNA G+C content $(\mathrm{mol} \%)$ & $35.6 \%$ & ND & $33.6 \%$ \\
\hline
\end{tabular}

Strains: 1, Flavobacterium amnigenum $\mathrm{I} 3-3^{\mathrm{T}} ; 2$, Flavobacterium nitrogenifigens $\mathrm{NXU}$ $44^{\mathrm{T}} ; 3$, Flavobacterium compostarboris $15 \mathrm{C} 3^{\mathrm{T}}$. Data obtained from the present study. +, substrate utilized / present; -, substrate not utilized/absent; w, weak growth/ activity; ND, not determined. All strains are gram-negative, non-motile, and positive for utilization of citrate, hydrolysis of skim milk, starch, tween-80, esculin, alkaline phosphatase, esterase (C4), esterase lipase (C8), leucine arylamidase, acid phosphatase, naphthol-AS-BI-phosphohydrolase, assimilation of D-glucose, D-galactose, D-mannose, $\mathrm{N}$-acetyl-glucosamine, amygdalin, D-cellobiose, D-maltose, amidon but negative for arginine dehydrolase, lysine decarboxylase, ornithine decarboxylase, $\mathrm{H}_{2} \mathrm{~S}$, indole production, tryptophan deaminase, gelatinase, glucose fermentation, arginine dehydrolase, lipase (C14), cystine arylamidase, trypsin, $\alpha$-chymotrypsin, $\alpha$-galactosidase, $\beta$-galactosidase, $\beta$-glucuronidase, $\alpha$-glucosidase, $N$-acetyl- $\beta$-glucosaminidase, $\alpha$-mannosidase, $\alpha$-fucosidase, assimilation of glycerol, erythritol, D-arabinose, L-arabinose, D-ribose, L-xylose, D-adonitol, methyl- $\beta$-D-xylopyranoside, L-sorbose, L-rhamnose, dulcitol, inositol, D-mannitol, D-sorbitol, methyl- $\alpha$-D-mannopyranoside, methyl$\alpha$-D-glucopyranoside, arbutin, D-melibiose, inuline, D-melezitose, D-raffinose, xylitol, gentiobiose, D-turanose, D-lyxose, D-tagatose, D-fucose, L-fucose, D-arabitol, L-arabitol, potassium gluconate, potassium 2-keto-gluconate, potassium 5-ketogluconate, capric acid, adipic acid, malic acid, and phenylacetic acid. 


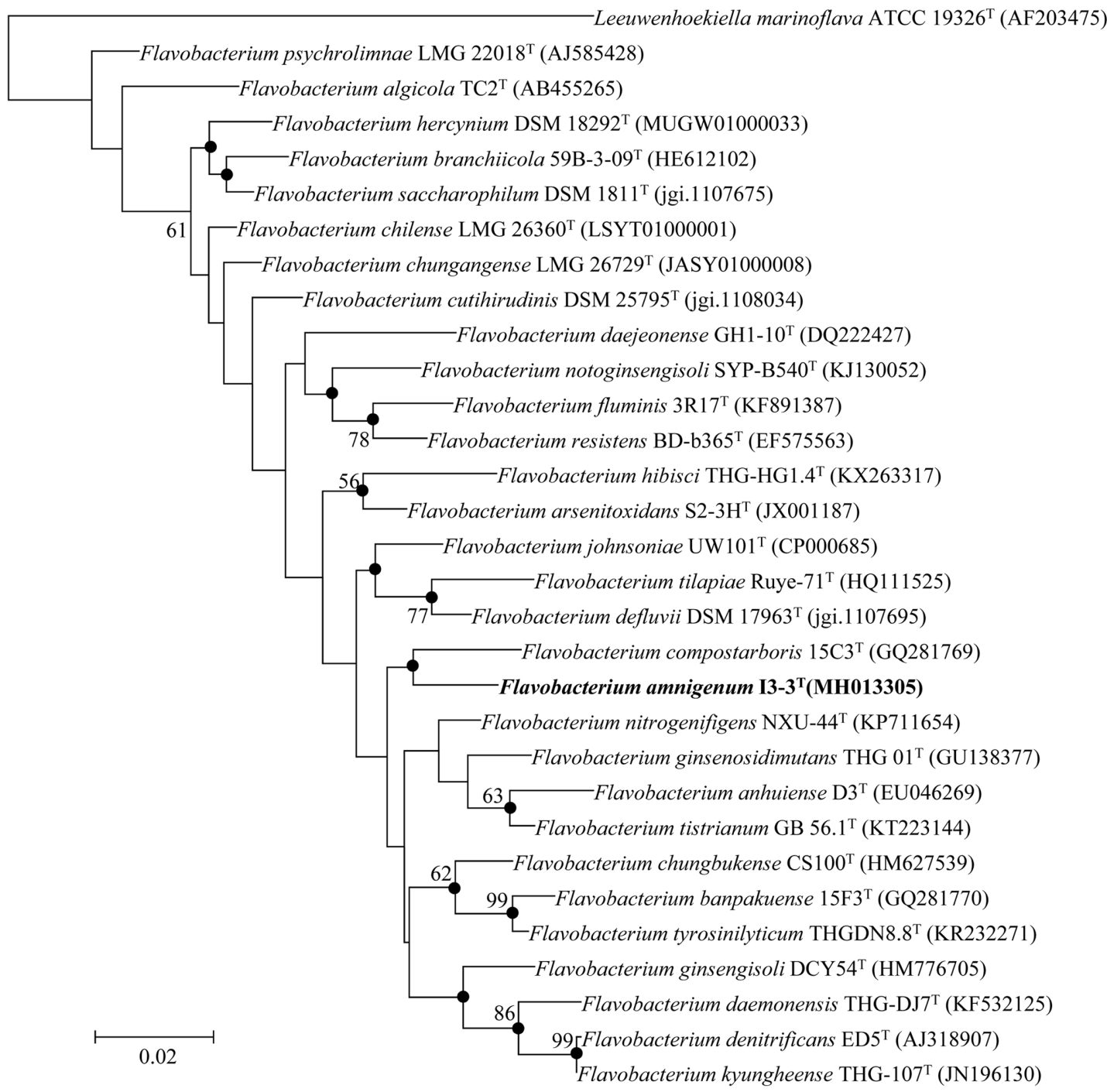

Fig. 1. Maximum likelihood tree depicting the phylogenetic position of strain $13-3^{\mathrm{T}}$ among the members of the genus Flavobacterium based on 16S rRNA gene sequences from EZBioCloud database (accession numbers in parentheses).

Multiple alignment, distance calculations (according to Kimura 2-parameter model), and clustering were performed using MEGA-6 software package. Bootstrap values $(\geq 50)$ based on 1,000 replications were shown at the nodes. Filled circles indicate that the corresponding nodes were also recovered in the trees reconstructed with neighbor-joining and minimum evolution algorithms. Leeuwenhoekiella marinoflava ATCC 19326 ${ }^{\mathrm{T}}$ (AF203475) was used as an outgroup. Bar, 0.02 nucleotide substitutions per nucleotide position.

phosphatidylethanolamine (PE), two aminolipids (AL1 and 2), and four unidentified lipids (UL1, 2, 3, and 4) (Fig. S3). Strain $\mathrm{I} 3-3^{\mathrm{T}}$ contained iso- $\mathrm{C}_{15: 0}$, iso- $\mathrm{C}_{17: 0} 3-\mathrm{OH}$ and summed feature 3 (comprising $\mathrm{C}_{16: 1} \omega 7 c$ and/or $\mathrm{C}_{16: 1} \omega 6 c$ ) as the major cellular fatty acids (>10\%) (Table 2). Menaquinone-6 (MK6) was the sole isoprenoid quinone in the cells of strain I3 $-3^{\mathrm{T}}$ which is in accordance with the description of the Flavobacterium genus.

Along with the phylogenetic distinctiveness, strain I3- $3^{\mathrm{T}}$ could also be differentiated from the closely related type strains, Flavobacterium nitrogenifigens NXU-44 ${ }^{\mathrm{T}}$ and Flavobacterium compostarboris $15 \mathrm{C}^{\mathrm{T}}$ by phenotypic characteristics such as colony morphology, acid production, enzyme activities, and fatty acid composition (Tables 1 and 2). This justifies the placement of strain $\mathrm{I} 3-3^{\mathrm{T}}$ as a novel species within the genus Flavobacterium for which the name Flavobacterium amnigenum sp. nov. is proposed.

\section{Description of Flavobacterium amnigenum sp. nov.}

Flavobacterium amnigenum (am.ni'ge.num. L. n. amnis any 
Table 2. Comparison of cellular fatty acid compositions of strain $\mathrm{I} 3-3^{\mathrm{T}}$ with those of its closest neighbours in the genus Flavobacterium.

\begin{tabular}{lccc}
\hline Fatty acid & 1 & 2 & 3 \\
\hline Saturated & tr & 1.2 & 1.0 \\
$\mathrm{C}_{14: 0}$ & 4.5 & 5.8 & 3.9 \\
$\mathrm{C}_{16: 0}$ & & & \\
Unsaturated & 2.0 & 3.9 & 3.2 \\
$\mathrm{C}_{15: 1} \omega 6 c$ & 1.6 & 2.3 & 2.6 \\
$\mathrm{C}_{17: 1} \omega 6 c$ & & & \\
Branched chain & 28.3 & 23.7 & 29.3 \\
iso- $\mathrm{C}_{15: 0}$ & 9.5 & 8.4 & 10.9 \\
iso- $\mathrm{C}_{15: 0} 3-\mathrm{OH}$ & 5.1 & 3.0 & 6.0 \\
iso- $\mathrm{C}_{15: 1} \mathrm{G}$ & 2.0 & 1.3 & 2.2 \\
iso- $\mathrm{C}_{16: 0} 3-\mathrm{OH}$ & 14.0 & 8.7 & 14.7 \\
iso- $\mathrm{C}_{17: 0} 3-\mathrm{OH}$ & 1.0 & tr & 1.0 \\
anteiso- $\mathrm{C}_{15: 0}$ & & & \\
Hydroxy & - & 2.2 & 1.7 \\
$\mathrm{C}_{15: 0} 3-\mathrm{OH}$ & 5.3 & 9.2 & 4.1 \\
$\mathrm{C}_{16: 0} 3-\mathrm{OH}$ & & & \\
Summed features* & 1.0 & 1.5 & 1.0 \\
2 & 16.2 & 20.7 & 11.1 \\
3 & 3.7 & 1.6 & 2.2 \\
\hline 2 & & & \\
\hline
\end{tabular}

Strains: 1, Flavobacterium amnigenum $\mathrm{I} 3-3^{\mathrm{T}} ; 2$, Flavobacterium nitrogenifigens NXU$44^{\mathrm{T}} ; 3$, Flavobacterium compostarboris $15 \mathrm{C}^{\mathrm{T}}$. Data obtained from the present study using cells grown on TSA at $30^{\circ} \mathrm{C}$ for $48 \mathrm{~h}$. Fatty acids representing $<1.0 \%$ of the total in all strains are not shown. tr, Trace $(<1.0 \%) ;-$, not detected. Summed feature 2 comprised of iso- $\mathrm{C}_{16: 1} \mathrm{I}$ and/or $\mathrm{C}_{14: 0} 3 \mathrm{OH}$; summed feature 3 comprised of $C_{16: 1} \omega 7 c$ and/or $C_{16: 1} \omega 6 c$; summed feature 9 comprised iso- $C_{17: 1} \omega 9 c$ and /or $C_{16: 0}$ 10-methyl.

broad and deep-flowing, rapid water; L. suff. genus -a -um (from L. v. gigno, to produce, give birth to, beget) born from; N.L. neut. adj. amnigenum coming from water).

Cells are rod shaped, gram-negative, aerobic, $1.0-4.0 \mu \mathrm{m}$ long and 0.3-0.4 $\mu \mathrm{m}$ wide, and non-motile. Growth occurs on TSA, brain heart infusion agar, R2A, LB, and NA but not on MacConkey agar at $30^{\circ} \mathrm{C}$ after $48 \mathrm{~h}$ incubation. Colonies on TSA are circular, 1-2 mm in diameter, convex, smooth, translucent, and yellowish with entire edges. The yellow pigment of flexirubin type is non-diffusible and nonfluorescent. No gliding motility and non-swarming. Spores are not formed. Catalase and oxidase positive but negative for Congo red absorption. Growth occurs between $10^{\circ} \mathrm{C}$ and $35^{\circ} \mathrm{C}$ with an optimal temperature of $30^{\circ} \mathrm{C}$. No growth occurs below $10^{\circ} \mathrm{C}$ or above $35^{\circ} \mathrm{C}$. Growth occurs at $\mathrm{NaCl}$ concentrations between $0 \%$ and $2 \%$ with optimum at $0.5 \%$.
Growth occurs between $\mathrm{pH} 5.0$ and 10.0 with an optimal $\mathrm{pH}$ 7.0. Starch, skim milk, and tween-80 are hydrolyzed but $\mathrm{CMC}$, casein, and tween-20 are not. Able to assimilate D-glucose, D-fructose, D-mannose, $\mathrm{N}$-acetylglucosamine, amygdalin, esculin, D-celiobiose, D-maltose, D-saccharose, amidon, and glycogen but not glycerol, erythritol, D-arabinose, L-arabinose, D-ribose, L-xylose, D-xylose, D-adonitol, methyl$\beta$-D-xylopyranoside, D-galactose, L-sorbose, L-rhamnose, dulcitol, inositol, D-mannitol, D-sorbitol, methyl- $\alpha-\mathrm{D}-$ mannopyranoside, methyl- $\alpha$-D-glucopyranoside, arbutin, salicin, D-lactose, D-trehalose, D-melibiose, inuline, D-melezitose, D-raffinose, xylitol, gentiobiose, D-turanose, D-lyxose, D-tagatose, D-fucose, L-fucose, D-arabitol, L-arabitol, potassium gluconate, potassium 2-keto-gluconate, potassium 5-keto-gluconate, capric acid, adipic acid, malic acid, and phenylacetic acid. Showed positive reaction for citrate utilization, nitrate reduction, alkaline phosphatase, esterase (C4), esterase lipase (C8), leucine arylamidase, acid phosphatase, naphthol-AS-BI-phosphohydrolase, and valine aryl amidase whereas negative reaction for $\mathrm{H}_{2} \mathrm{~S}$, acetoin, and indole production, ONPG hydrolysis, tryptophane deaminase, gelatinase, urease, arginine dehydrolase, lysine decarboxylase, ornithine decarboxylase, lipase (C14), cysteine arylamidase, trypsin, $\alpha$-chymotrypsin, $\alpha$-galactosidase, $\beta$-galactosidase, $\beta$-glucuronidase, $\alpha$-glucosidase, $N$-acetyl$\beta$-glucosaminidase, $\alpha$-mannosidase, $\alpha$-fucosidase, and $\beta$-glucosidase. The predominant polar lipids are phosphatidylethanolamine, one aminolipid, and two unidentified lipids. The major fatty acids are iso- $\mathrm{C}_{15: 0}$, iso$\mathrm{C}_{17: 0} 3-\mathrm{OH}$ and summed feature 3 comprising of $\mathrm{C}_{16: 1} \omega 7 c$ and/or $C_{16: 1} \omega 6 c$. Major respiratory quinone is MK-6. The DNA G+C content of the type strain is $35.6 \mathrm{~mol} \%$.

The type strain $13-3^{\mathrm{T}}\left(=\mathrm{KCTC} 52884^{\mathrm{T}}=\mathrm{NBRC} 112871^{\mathrm{T}}\right)$ was isolated from a freshwater river in Iksan, the Republic of Korea.

\section{Acknowledgments}

We thank Prof. Aharon Oren for his expert suggestion for correct species epithet and Latin etymology. This study was supported by the Korea Healthcare Technology R\&D Project, Ministry of Health and Welfare, Republic of Korea (2017N-ER5405-00) and the Korea Ministry of Environment (MOE) as "The Environmental Health Action Program" under Project No. 2016001350005.

\section{Conflict of Interest}

The authors have no financial conflicts of interest to declare. 


\section{References}

1. Bergey D, Harrison F, Breed R, Hammer B, Huntoon F. 1923. Genus II. Flavobacterium gen. nov, pp. 97-117. Bergey's Manual of Determinative Bacteriology, 1 Ed. Williams and Wilkins, Baltimore, MD.

2. Liu Y, Jin JH, Zhou YG, Liu HC, Liu ZP. 2010. Flavobacterium caeni sp. nov., isolated from a sequencing batch reactor for the treatment of malachite green effluents. Int. J. Syst. Evol. Microbiol. 60: 417-421.

3. Choi S, Shin SK, Kim E, Yi H. 2017. Flavobacterium crassostreae sp. nov., isolated from Pacific oyster. Int. J. Syst. Evol. Microbiol. 67: 988-992.

4. Bernardet JF, Segers P, Vancanneyt M, Berthe F, Kersters K, Vandamme P. 1996. Cutting a gordian knot: emended classification and description of the genus Flavobacterium, emended description of the family Flavobacteriaceae, and proposal of Flavobacterium hydatis nom nov. (basonym, Cytophaga aquatilis Strohl and Tait 1978). Int. J. Syst. Evol. Microbiol. 46: 128-148.

5. Bernardet J, Bowman J. 2006. The genus Flavobacterium, pp. 481-531. In Dworkin M, Falkow S, Rosenberg E, Schleifer KH, Stackebrandt E (eds.), The Prokaryotes, Springer, New York. USA.

6. Padakandla SR, Lee G-W, Chae J-C. 2015. Paenibacillus gelatinilyticus sp. nov. a psychrotolerant bacterium isolated from reclaimed soil and amended description of Paenibacillus shenyangensis. Antonie Van Leeuwenhoek 108: 1197-1203.

7. Yoon SH, Ha SM, Kwon S, Lim J, Kim Y, Seo H, Chun J. 2017. Introducing EzBioCloud: a taxonomically united database of 16S rRNA gene sequences and whole-genome assemblies. Int. J. Syst. Evol. Microbiol. 67: 1613-1617.

8. Tamura K, Stecher G, Peterson D, Filipski A, Kumar S. 2013. MEGA6: molecular evolutionary genetics analysis version 6.0. Mol. Biol. Evol. 30: 2725-2729.

9. Kimura M. 1983. The Neutral Theory of Molecular Evolution. Cambridge University Press, Cambridge.

10. Felsenstein J. 1985. Confidence limits on phylogenies: an approach using the bootstrap. Evolution 39: 783-791.

11. Bernardet JF, Nakagawa Y, Holmes B. 2002. Proposed minimal standards for describing new taxa of the family Flavobacteriaceae and emended description of the family. Int. J. Syst. Evol. Microbiol. 52: 1049-1070.

12. Tindall BJ, Rosselló-Móra R, Busse H-J, Ludwig W, Kämpfer P. 2010. Notes on the characterization of prokaryote strains for taxonomic purposes. Int. J. Syst. Evol. Microbiol. 60: 249-266.

13. Buck JD. 1982. Nonstaining (KOH) method for determination of gram reactions of marine bacteria. Appl. Environ. Microbiol. 44: 992-993.

14. Sirra MRS, Padakandla SR, Chae J-C. 2017. Soonwooa purpurea sp. nov., isolated from a fresh water river. Int. J. Syst. Evol. Microbiol. 67: 5193-5197.

15. Schaeffer AB, Fulton MD. 1933. A simplified method of staining endospores. Science 77: 194.

16. Cappuccino J, Sherman N. 1998. Microbiology - A Laboratory Manual, 4th Ed. Benjamin/Cummings Science Publishing, San Francisco, CA.

17. Smibert R, Krieg N. 1994. Phenotypic characterization, pp. 607-654. In Gerhardt P, Murray R, Wood W, Krieg N (eds.), Methods for General and Molecular Bacteriology. American Society for Microbiology, Washington DC, USA.

18. Bauer AW, Kirby WMM, Sherris JC, Turck M. 1966. Antibiotic susceptibility testing by a standardized single disk method. Am. J. Clin. Pathol. 45: 493-496.

19. Minnikin DE, ÓDonnell AG, Goodfellow M, Alderson G, Athalye M, Schaal A, et al. 1984. An integrated procedure for the extraction of bacterial isoprenoid quinones and polar lipids. J. Microbiol. Methods 2: 233-241.

20. Tindall B, Sikorski J, Smibert R, Kreig N. 2007. Phenotypic characterization and the principles of comparative systematics. pp. 330-393. In Reddy CA, Beveridge TJ, Breznak JA, Marzluf G, Schmidt TM, Snyder LR (eds), Methods for General and Molecular Microbiology, 3rd Ed. American Society for Microbiology, Washington DC, USA.

21. Kates M. 1972. Techniques of lipidology, Elsevier, New York, USA.

22. Oren A, Duker S, Ritter S. 1996. The polar lipid composition of walsby's square bacterium. FEMS Microbiol. Lett. 138: 135-140.

23. Sasser M. 2001. Identification of bacteria by gas chromatography of cellular fatty acids. MIDI Technical Note 101.

24. Tamaoka J, Katayama-Fujimura Y, Kuraishi H. 1983. Analysis of bacterial menaquinone mixtures by high-performance liquid chromatography. J. Appl. Bacteriol. 54: 31-36.

25. Marmur J. 1961. A procedure for the isolation of deoxyribonucleic acid from microorganisms. J. Mol. Biol. 3: 208-218.

26. Mesbah M, Premachandran U, Whitman WB. 1989. Precise measurement of the $\mathrm{G}+\mathrm{C}$ content of deoxyribonucleic acid by high-performance liquid chromatography. Int. J. Syst. Bacteriol. 39: 159-167. 